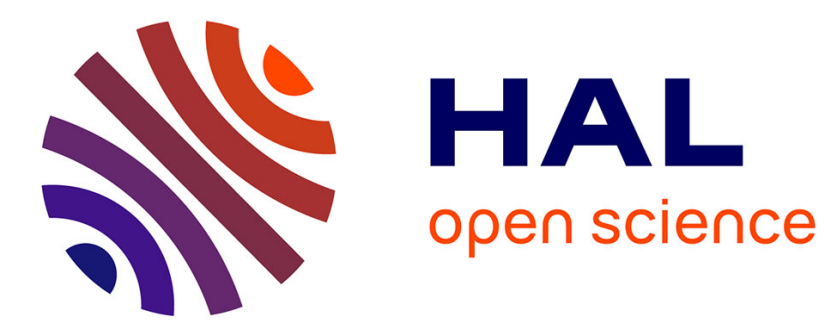

\title{
Application of a PEG/salt aqueous two-phase partition system for the recovery of monoclonal antibodies from unclarified transgenic tobacco extract
}

Dimitris Platis, Nikolaos Labrou

\section{- To cite this version:}

Dimitris Platis, Nikolaos Labrou. Application of a PEG/salt aqueous two-phase partition system for the recovery of monoclonal antibodies from unclarified transgenic tobacco extract. Biotechnology Journal, 2009, 4 (6), pp.1320. 10.1002/biot.200800359 . hal-00495061

\section{HAL Id: hal-00495061 \\ https://hal.science/hal-00495061}

Submitted on 25 Jun 2010

HAL is a multi-disciplinary open access archive for the deposit and dissemination of scientific research documents, whether they are published or not. The documents may come from teaching and research institutions in France or abroad, or from public or private research centers.
L'archive ouverte pluridisciplinaire HAL, est destinée au dépôt et à la diffusion de documents scientifiques de niveau recherche, publiés ou non, émanant des établissements d'enseignement et de recherche français ou étrangers, des laboratoires publics ou privés. 


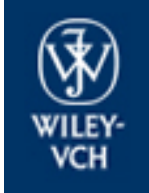

Biotechnology Journal

\section{Application of a PEG/salt aqueous two-phase partition system for the recovery of monoclonal antibodies from unclarified transgenic tobacco extract}

\begin{tabular}{|c|c|}
\hline Journal: & Biotechnology Journal \\
\hline Manuscript ID: & BIOT-2008-0359.R2 \\
\hline Wiley - Manuscript type: & Research Article \\
\hline $\begin{array}{l}\text { Date Submitted by the } \\
\text { Author: }\end{array}$ & 30-Mar-2009 \\
\hline Complete List of Authors: & $\begin{array}{l}\text { Platis, Dimitris; Agricultural University of Athens, Agricultural } \\
\text { Biotechnology } \\
\text { Labrou, Nikolaos; Agricultural University of Athens, Agricultural } \\
\text { Biotechnology }\end{array}$ \\
\hline Keywords: & $\begin{array}{l}\text { Aqueous two phase system, molecular farming, downstream } \\
\text { processing, therapeutic monoclonal antibody, transgenic plants }\end{array}$ \\
\hline
\end{tabular}

\section{s ScholarONE" \\ Manuscript Central}




\title{
Research Article ((4760 words))
}

\section{Application of a PEG/salt aqueous two-phase partition} system for the recovery of monoclonal antibodies from

\author{
unclarified transgenic tobacco extract
}

D. Platis and N.E. Labrou*

Enzyme Technology Laboratory, Department of Agricultural Biotechnology,

Agricultural University of Athens, 75 Iera Odos, GR 11855 Athens, Greece

* To whom all correspondence should be addressed

Tel and fax: +30 210 5294308, e-mail: lambrou@aua.gr 
Keywords

Aqueous two phase system; downstream processing; molecular farming; therapeutic monoclonal antibody; transgenic plants

\begin{abstract}
Abbreviations
$\mathrm{CCD}$, central composite design; ELISA, enzyme-linked immunosorbent assay; mAb 2G12/4E10, human anti-HIV 2G12/4E10 monoclonal antibody; PEG, polyethylenoglycol; Pi, phosphate; SDS-PAGE, sodium sulphate dodecyl polyacrylamide gel electrophoresis; TBS, Tris buffered saline; TCA, trichloroacetic acid
\end{abstract}




\section{Abstract}

Aqueous two phase partition systems (ATPS) have been widely used for the separation of large variety of biomolecules. In the present report, the application of a polyethyleneglycol/phosphate (PEG/Pi) ATPS for the separation of anti-HIV monoclonal antibodies 2G12 (mAb 2G12) and 4E10 (mAb 4E10) from unclarified transgenic tobacco crude extract was investigated. Optimal conditions that favour opposite phase partitioning of plant debris $/ \mathrm{mAb}$ as well as high recovery and purification were found to be $13.1 \% \mathrm{w} / \mathrm{w}$ [PEG 1500], 12.5\% w/w [Pi] at $\mathrm{pH} 5$ with a phase ratio of 1.3 and $8.25 \% \mathrm{w} / \mathrm{w}$ unclarified tobacco extract load. Under these conditions, mAb 2G12 and mAb 4E10 were partitioned at the bottom phosphate phase with 85 and $84 \%$ yield and purification 2.4- and 2.1-fold, respectively. The proposed ATPS was successfully integrated in an affinity-based purification protocol, using Protein A, yielding antibodies of high purity and yield. From this study, ATPS was shown to be suitable for initial protein recovery and partial purification of mAbs from unclarified transgenic tobacco crude extract. 


\section{Introduction}

The application of aqueous two-phase systems (ATPS) in protein recovery has received considerable attention. ATPS offer low-cost, easily scalable, environmentally benign as well as multifunctional operations $[1-4] . \mathrm{PEG} /$ salt systems, in particular, are widely applied for bioseparation of proteins because they are cost-effective low viscocity systems, suitable for continuous large scale operations, present shorter sepration times and able to handle high biomass load [5-8]. The bulk of both phases consist mainly of water (80-90\%). PEG has a stabilising effect on the protein tertiary structure, offering thus a gentle biocompatible nontoxic environment for labile biomolecules at which biological activity and protein solubility is maintained [9]. A variety of operational conditions, such as choice and concentration of polymer, salt, $\mathrm{pH}$ can be manipulated in order to achieve differential partitioning of the protein of interest. Differential partitioning mainly depends on surface properties (such as the size, charge and hydrophobicity) of the protein as well as on the physicochemical traits of the two phases [10-12]. Despite the fact that recovery of monoclonal antibodies from complex biological tissues has been reported in several studies, the wide-scale application of ATPS has been hindered by the poorly-understood partitioning mechanism $[13,11]$.

Future progress in utilizing transgenic plants for biopharmaceuticals production will depend on the efficiency of the purification methods, since purification represents most of the cost of biopharmaceutical production in transgenic plants $[14,15]$. Therefore, new approaches are necessary to minimize or eliminate purification costs. Several chromatographic strategies have been investigating so far. These include cation exchange chromatography [16], anion exchange chromatography [17], 
metal chelate affinity chromatography $[18,19]$, polyelectrolyte precipitation [20], Protein A affinity chromatography [21], and biomimetic affinity chromatography $[22,23]$. ATPS is a pre-purification/concentration method that offers potential for product capture integrated with solids removal. ATPS has been evaluated for purifying egg white lysozyme [24] and mAb 2F5 and 2G12 using clarified tobacco extracts $[25,26]$. In this latter study, the effect of PEG molecular weight, $\mathrm{pH}$ and tie line length, as well as the overall potential use of PEG/phosphate aqueous twophase systems for the recovery and purification of mAbs $2 \mathrm{~F} 5$ and $2 \mathrm{G} 12$ were examined in Platis et al., 2006 [25]. Similarities in the partitioning behaviour of monoclonal antibodies, especially of the same subclass (IgG1) have been observed in the literature probably due to overall similarities in general structural and physicochemical characteristics $[27,28]$. Therefore, in the present study, ATPS optimization was achieved by analyzing the factors influencing the partitioning of $\mathrm{mAb} 2 \mathrm{G} 12$ and tobacco proteins, based on initial parameter range discovery as published previously [25]. This allowed the use of a standard two-parameter Central Composite Design (CCD) for a narrow range of PEG and phosphate concentrations on multiple PEG MWs, in order to predict conditions of optimal differential plant debris separation, purification and yield $[29,30]$. All pertaining experiments were conducted at $\mathrm{pH}$, which was found to be optimal for extraction and partitioning [25].

Protein isolation and purification from plants is a difficult task, owing to the complexity of the plant system and the presence of phenolic compounds, pigments, and mucilages $[14,31]$. The presence of such compounds is potential interfering factor in downstream processing and has to be addressed early in the isolation process. 
For example, the presence of phenols and anionic polysaccharides can cause problems during chromatographic purification since they bind strongly to the chromatographic matrices and may give them ion-exchange characteristics [32-34] or potentially reduce their half-life [25]. The presence of these compounds may strongly bind, inactivate and modify recombinant proteins expressed in transgenic plants $[35,36]$. This can have a detrimental effect on the structural integrity, purity and function of the isolated protein. The economic impact of these metabolites on the downstream process, especially on an industrial scale, has not been adequately addressed.

Plant biotechnology has demonstrated that transgenic plants are suitable hosts for expressing recombinant biomolecules. Several reagent-grade recombinant proteins from transgenic corn (trypsin and avidin) $[37,38]$ and rice (lysozyme and lactoferin) $[39,40]$ have been commercialized, while clinical trials for plant-derived therapeutic proteins (e.g. interferon alpha-2b) are underway [ 41$]$.

In the present study, the application of ATPS for the recovery of mAbs from unclarified crude tobacco extract was evaluated. This is the first report of using ATPS as a pre-processing plant debris removal tool in the downstream processing procedure for the purification of monoclonal antibodies from transgenic tobacco. The results showed that the system offers significant advantages by minimizing intervening processing steps, such as centrifugation or filtration. The high cost of filtration or centrifugation for pre-chromatography processing, necessary to remove plant debris, makes it prohibitive at a large scale [42]. At the same time the system acts as a guard, increasing the performance and capacity of subsequent chromatographic steps. 


\section{Materials and Methods}

\subsection{Materials}

Transgenic Nicotiana tabacum seeds expressing mAb 4E10 were kindly donated by Prof. J. Ma (St. George's, University of London, UK). Transgenic Nicotiana tabacum seeds expressing mAb 2G12 were kindly donated by Prof. R. Fischer (Institute for Molecular Biotechnology, Aachen, Germany). CHO-derived and purified human monoclonal anti-HIV 2G12 and 4E10 antibodies were kindly donated by Dr. Dietmar Katinger at Polymun Scientific. PEG (molecular masses 1500, 3000 and 6000), potassium phosphate monobasic, potassium phosphate dibasic, polyclonal antibody [goat anti-human-IgG ( $\gamma$-chain) (GAH-IgG)], polyclonal antibody [goat anti-humanIgG ( $\kappa$-chain) (GAH-IgG \& AP)] conjugated to alkaline phosphatase, was obtained from Sigma-Aldrich (St. Louis, MO, USA). All other chemicals were of analytical grade.

\subsection{Methods}

\subsubsection{Plant growth}

Transgenic Nicotiana tabacum seeds were pre-germinated on plates, on filter paper, Whatman 3MM (watered with distilled water). The plates were kept for $72 \mathrm{hrs}$ at $30^{\circ} \mathrm{C}$. After germination, the plants were transferred into plastic pots (1-2 plants in each pot), in soil. The plants were grown in a controlled environment (12 h day/12 $\mathrm{h}$ night cycle, at $25^{\circ} \mathrm{C}$ day $/ 21^{\circ} \mathrm{C}$ night-regime and $65 \%$ humidity. The plants were watered with deionized water every 2 days.

\subsubsection{Monoclonal antibody 2 G12 and 4 E10 extraction from transgenic tobacco} leaves 
Aqueous extraction of mAbs $2 \mathrm{G} 12$ and $4 \mathrm{E} 10$ from transgenic tobacco leaves was performed by mixing $5 \mathrm{~g}$ of tobacco leaves with $15 \mathrm{~mL}$ of $50 \mathrm{mM}$ sodium phosphate buffer $\mathrm{pH}$ 5.0. Subsequently, the sample was disintegrated in a blender (total $10 \mathrm{~min}$, breaking every $15 \mathrm{~s}$ ) and the crude mixture placed on a rotary mixer for $60 \mathrm{~min}$ at $4^{\circ} \mathrm{C}$. The amount of protein and monoclonal antibody extracted was determined by the method of Bradford [43] and ELISA [26], respectively. The expression level of mAbs $2 \mathrm{G} 12$ and 4E10 in transgenic tobacco were approximately $0.5-1 \% \mathrm{w} / \mathrm{w}$ in the total soluble protein (TSP) extracted fraction.

\subsubsection{Aqueous Two Phase System (ATPS)}

Phase diagrams for PEG-phosphate systems have been previously reported $[44,45]$. Preparation of the phase systems was done from stock solutions of PEG $50 \% \mathrm{w} / \mathrm{w}$ and phosphate $40 \% \mathrm{w} / \mathrm{w}$. In the case of the phosphate stock solution the appropriate working solution was achieved by mixing appropriate amounts of $\mathrm{K}_{2} \mathrm{HPO}_{4}$ and $\mathrm{NaH}_{2} \mathrm{PO}_{4}$ until the desired $\mathrm{pH}$ was achieved. ATPS systems (20 g) were prepared by mixing the sample (final concentration: $8.25 \% \mathrm{w} / \mathrm{w}$ crude transgenic tobacco extract), water and phosphate buffer, followed by gradual addition of the appropriate amount of 50\% (w/w) PEG. Gradual addition of PEG was necessary in order to avoid precipitation of the sample due to increased PEG concentration. Following thorough mix of the systems they were allowed to equilibrate at room temperature for 1-24 hrs without centrifugation. Samples were removed at specific time points from the top and bottom phases in order to calculate total protein and mAb 2 G12 partitioning. Total plant protein was added in the samples to a final concentration of $0.3-0.35 \mathrm{~g} / \mathrm{L}$. Control systems without protein (containing extraction buffer) were used for reference and comparison. Estimation of the volume of the top 
and bottom phases was done visually in graduated centrifuge tubes and the volume ratio was subsequently calculated $\left(\mathrm{V}_{\mathrm{r}}=\right.$ volume of top phase/volume of bottom phase). Total protein and antibody concentration was determined by Bradford assay and ELISA respectively. The following parameters were evaluated : (a) Yield of mAb $2 \mathrm{G} 12$ (the amount of mAb 2G12 in the bottom phase/initial mAb 2G12 added into the whole system) and (b) Purification factor Purification factor, defined as the ratio:

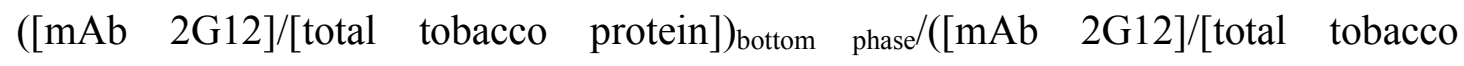
protein]) crude extract.

\subsubsection{Full Central Composite Design}

A two-level full Central Composite Design (CCD) was used in order to study the partitioning behaviour of tobacco proteins and mAb 2G12 and determine the effect of PEG and phosphate (Pi) concentrations at different PEG MW conditions. The variables were studied at two levels and for each variable studied, high (coded value +1 ) and low (coded value: -1$)$ set points were selected based on results obtained from previous experiments [25] and considering the experimental conditions required for phase and debris separation. The ranges of factors are PEG molecular weight (15006000), PEG concentration (11-15\% w/w) and phosphate concentration $(11-15 \% \mathrm{w} / \mathrm{w})$ at $\mathrm{pH} 5$ and crude transgenic tobacco extract load $8.25 \% \mathrm{w} / \mathrm{w}$. To set up a design, the inputs of each factor and its level as well as all responses are required. The responses were percentage of mAb $2 \mathrm{G} 12$ bottom phase recovery and purification factor. All experiments were analyzed using MINITAB (edition 14) software for statistical analysis and response optimization.

\subsubsection{Sodium dodecyl sulphate polyacrylamide gel electrophoresis (SDS-PAGE).}


A $12.5 \%(\mathrm{w} / \mathrm{v})$ reducing SDS-PAGE was carried out as described in Platis et al., 2008 $[26]$.

\subsubsection{Affinity chromatography on Protein A column.}

Affinity chromatography on Protein A column was conducted according to Platis et al., 2006 [25]. Briefly, a column packed with protein A adsorbent $(0.5 \mathrm{~mL})$ was equilibrated with potassium phosphate buffer $(20 \mathrm{mM}, 150 \mathrm{mM} \mathrm{NaCl}, \mathrm{pH} 7.0,10 \mathrm{~mL})$ and the antibody sample (bottom phase ATPS, approximately $0.5 \mathrm{ml}$, diluted to $10 \mathrm{~mL}$ with equilibration buffer). The column was washed with potassium phosphate buffer (20 mM, 0.15 mM NaCl, pH 7.0, $10 \mathrm{~mL}$ ). Bound antibody was eluted with glycine$\mathrm{HCl}$ buffer (0.1 M, pH 2.5, $2 \mathrm{~mL})$.

\subsubsection{Determination of total phenolics and alkaloids.}

Determination of total phenolics and alkaloids in samples from tobacco extract was carried out as described in Platis \& Labrou (2006) [25 ].

\section{Results and Discussion}

The previously designed ATPS systems $[25,26]$ did not account for the influence of interfering factors such as, cell fragments and debris that are present in the crude tobacco leaf extract, since the added tobacco extract had been clarified by centrifugation, following by filtration. In order to take full advantage of the partitioning potential of ATPS, the ATPS conditions were adopted so that mAb separation would be possible using unclarified crude extract, therefore avoiding initial centrifugation and filtration steps. 
All experiments were analyzed using MINITAB (edition 14) software for statistical analysis and response optimization. Selection of optimal ATPS system conditions was based on differential plant debris separation, purification and yield. Based on previous bibliography, a series of pilot experiments was designed to determine whether such a favourable plant debris partitioning was possible. Initial experiments showed that ATPS systems based on PEG 3000 and PEG 6000 (data not shown) were unable to separate plant debris concentrate from mAb $2 \mathrm{G} 12$ (tested at a variety of conditions at both short and long TLLs) and were subsequently dismissed from further investigation. It was found that only PEG 1500 was able to achieve opposite phase partitioning of plant debris/mAb $2 \mathrm{G} 12$, which is in accordance with previous published results $[46,47]$. For this reason, as well as the previous preference of PEG 1500-containing ATPS systems for mAb 2G12 partitioning [26] which exhibited higher yield and purification ability than PEG 3000- and PEG 6000containing ATPS systems, the attention was focused towards the analysis of ATPS conditions in PEG 1500-containing systems that favour opposite phase partitioning of plant debris/mAb 2G12. We have previously shown that ATPS conditions close to the binodal curve (short TLLs) are optimal for mAb 2G12 partitioning [25]. Pilot screening experiments showed that ATPS conditions with low phosphate concentrations (lower than 11\% w/w) despite exhibiting high yield and purifying ability also exhibited significant plant debris and polyphenol leakage to the bottom phase and were therefore not selected. Increasing the phosphate concentration $(>12 \%$ w/w) substantially improved plant debris separation (Figure 1). Therefore, initially we have methodically scanned the putative, predicted area of interest identifying not only the crossover point of the binodal curve but also roughly examining the effect of PEG 
and phosphate concentration on plant debris separation and leakage to the bottom phase.

Based on this initial information a standard two-parameter full CCD was chosen, concentrating of ATPS conditions close to the tie line, which proved to favour plant debris separation (Table 1). The contour plots as well as response optimization indicated the desirable combination of variables to obtain the most efficient conditions for maximum simultaneous mAb $2 \mathrm{G} 12$ recovery in the bottom phase and purification (Figure 2). Although $\mathrm{V}_{\mathrm{t}} / \mathrm{V}_{\mathrm{b}}$ ratio was also considered as a factor for the design of the CCD, however, previous attempts to design ATPS systems with very high $V_{t} / V_{b}$ ratios resulted in significant problems with mAb 2G12 precipitation (i.e. low TLL conditions with $[\mathrm{PEG}]>20 \% \mathrm{w} / \mathrm{w})$, therefore resulting in a lower yield [26]. For this reason the CCD was designed so that it would produce the highest possible $V_{t} / V_{b}$ ratios without compromising yield. In order to maximize the processing capacity of the ATPS the maximum possible transgenic tobacco extract load of $8.25 \% \mathrm{w} / \mathrm{w}$ was adopted for all ATPS experiments. Higher protein load in ATPS reduced the purifying ability of the ATPS system.

Since the goal was to use ATPS for plant debris removal, avoiding centrifugation/filtration steps, the systems were allowed to separate under gravity at room temperature. The time that is required for complete phase separation of the system (20-50 g) was approximately between 1-3 h, depending on phase composition. Between 1-3 h mAbs remained stable as determined by ELISA assay [25]. To simulate this equilibration period the systems were also left for $24 \mathrm{~h}$ at room temperature in order to test the stability of mAbs in solution as well as the stability of the ATPS. 
Results showed that key parameters, such mAb bottom phase yield and purification factor, remained relatively unaltered during this time period (Table 1), although it is obvious that prolonged exposures of the antibody with the unclarified tobacco extract should be avoided in order to minimize detrimental effects such as protease degradation or polyphenol-antibody interactions. Optimal recovery and purification conditions were predicted, based on the CCD analysis presented and taking into account the additional screening of the area close to the binodal, to be $13.1 \% \mathrm{w} / \mathrm{w}$ [PEG 1500], 12.5\% w/w [Pi] at $\mathrm{pH} 5$ with a $\mathrm{V}_{\mathrm{t}} / \mathrm{V}_{\mathrm{b}}$ phase ratio of 1.3 and $8.25 \% \mathrm{w} / \mathrm{w}$ transgenic tobacco extract load. These conditions were evaluated using an $80 \mathrm{~g}$ aqueous two phase system and the results are presented in Table 2. Under these conditions, $\mathrm{mAb} 2 \mathrm{G} 12$ and $\mathrm{mAb} 4 \mathrm{E} 10$ were partitioned at the bottom phosphate phase with 85 and $84 \%$ yield and purification factor of 2.4 and 2.1 , respectively. The final chosen ATPS conditions for debris separation provide similar mAbs yields as in the $\underline{\text { case of mAb purification from clarified plant extract [26]. In addition, plant debris }}$ does not appear to have any effect on mAb stability in the crude mixture for up to 3 hours tested. It should be noted, that $\mathrm{mAb}$ partitioning at the bottom phase with $\underline{\text { simultaneous debris partitioning seriously minimizes the number of useful conditions }}$ for efficient partitioning. However, by carefully screening the area close to the binodal we have managed to isolate a set of conditions that provide satisfactory results.

To further demonstrate the usefulness and necessity of the ATPS, we have attempted to incorporate this step into the common purification strategy that is routinely used by antibody manufacturers e.g. affinity chromatography on Protein A, aiming at purifying the mAbs to homogeneity. Affinity chromatography with Protein A is the most selective method for mAb purification and is conventionally used for the initial 
capturing step to facilitate rapid volume reduction as well as separation of the antibody. The affinity chromatography step was carried out according to the standard procedures commonly employed by antibody manufacturers [25]. The results showed that the incorporation of the ATPS step before affinity chromatography does not affect the effectiveness of the whole procedure. This is because the antibody fraction obtained from the ATPS requires no dialysis or ultrafiltration (for buffer exchange) prior to loading onto the affinity column. The initial and final concentration of mAbs $2 \mathrm{G} 12$ and $4 \mathrm{E} 10$ was approximately $5-7 \mu \mathrm{g} / \mathrm{ml}$ (in the plant extract) and 3-5 $\mu \mathrm{g} / \mathrm{ml}$ (after Protein A purification) respectively. The initial and final concentration of total protein were $800-1000 \mu \mathrm{g} / \mathrm{ml}$ and $<0.5 \mu \mathrm{g} / \mathrm{ml}$. Analysis of purified antibody by SDS-PAGE showed the absence of any major contaminating proteins or degraded antibody variants (Figure 3).

$\underline{\text { In conclusion, ATPS offers unique advantages for large scale processing e.g. low cost, }}$ easy scale up, continuous processing and high biocompatibility. In addition, the system allows fast approach to equilibrium and therefore high separation rates, a crucial factor for minimizing the time that the heterologous protein is exposed to deleterious plant extract. Thus, the present method provides a simple and effective way of preparing therapeutic antibodies in two steps (ATPS, affinity chromatography) $\underline{\text { suitable for analytical or clinical purposes. }}$

\section{Acknowledgments.}

The authors thank the European Union for the financial assistance provided. This work was performed within the framework of the Pharma-Planta research project (No 503565). 


\section{References}

1 Ferreira,I.F., Azevedo,A.M., Rosa,P.A., and Aires-Barros,M.R. Purification of human immunoglobulin $\mathrm{G}$ by thermoseparating aqueous two-phase systems. J Chromatogr.A 2008, 1195, 94-100

2 Johansson,H.O., Magaldi,F.M., Feitosa,E., and Pessoa,A., Jr. Protein partitioning in poly(ethylene glycol)/sodium polyacrylate aqueous twophase systems. J Chromatogr.A 2008, 1178, 145-153

3 Pericin,D.M., Madarev-Popovic,S.Z., and Radulovic-Popovic,L.M. Optimization of conditions for acid protease partitioning and purification in aqueous two-phase systems using response surface methodology. Biotechnol.Lett. 2008, 31, 43-47

4 Salgado,J.C., Andrews,B.A., Ortuzar,M.F., and Asenjo,J.A. Prediction of the partitioning behaviour of proteins in aqueous two-phase systems using only their amino acid composition. J Chromatogr.A 2008, 1178, 134-144

5 Albertsson,P.A. Partition of cell particles and macromolecules in polymer twophase systems. Adv.Protein Chem. 1970, 24, 309-341

6 Flanagan,J.A., Huddleston,J.G., and Lyddiatt,A. Application of aqueous twophase partition in PEG-phosphate systems. Design and implementation of a prototype process for recovery of bulk protein fractions from waste brewer's yeast. Bioseparation. 1991, 2, 43-61

7 Hustedt, H., Kroner, K.H., and Kula M.R. In: Walter, H., Brooks, D.E., and Fisher, D. (Eds.), Partitioning in Aqueous Two-Phase Systems: Theory, Methods, Uses and Applications to Biotechnology. Academic Press, New York 1985, p.529

8 Kula,M.R., Kroner,K.H., Hustedt,H., and Schutte,H. Technical aspects of extractive enzyme purification. Ann.N.Y.Acad.Sci. 1981, 369, 341-354

9 Dreyer,S. and Kragl,U. Ionic liquids for aqueous two-phase extraction and stabilization of enzymes. Biotechnol.Bioeng. 2008, 99, 1416-1424

10 Andrews,B.A., Schmidt,A.S., and Asenjo,J.A. Correlation for the partition behavior of proteins in aqueous two-phase systems: effect of surface hydrophobicity and charge. Biotechnol.Bioeng. 2005, 90, 380-390

11 Huddleston,J., Veide,A., Kohler,K., Flanagan,J., Enfors,S.O., and Lyddiatt,A. The molecular basis of partitioning in aqueous two-phase systems. Trends in Biotechnology 1991, 9, 381-388

12 Rosa,P.A., Azevedo,A.M., Ferreira,I.F., de Vries,J., Korporaal,R., Verhoef,H.J., Visser,T.J., and Aires-Barros,M.R. Affinity partitioning of human antibodies in aqueous two-phase systems. J Chromatogr.A 2007, 1162, 103-113 
13 Azevedo,A.M., Rosa,P.A., Ferreira,I.F., and Aires-Barros,M.R. Chromatography-free recovery of biopharmaceuticals through aqueous two-phase processing. Trends Biotechnol. 2009, 27, 240-247

14 Hassan,S., van Dolleweerd,C.J., Ioakeimidis,F., Keshavarz-Moore,E., and Ma,J.K. Considerations for extraction of monoclonal antibodies targeted to different subcellular compartments in transgenic tobacco plants. Plant Biotechnol.J 2008, 6, 733-748

15 Lienard,D., Sourrouille,C., Gomord,V., and Faye,L. Pharming and transgenic plants. Biotechnol.Annu.Rev 2007, 13, 115-147

16 Zhang,C. and Glatz,C.E. Process engineering strategy for recombinant protein recovery from canola by cation exchange chromatography.

Biotechnol.Prog. 1999, 15, 12-18

17 Wang,C., Soice,N.P., Ramaswamy,S., Gagnon,B.A., Umana,J., Cotoni,K.A., Bian,N., and Cheng,K.S. Cored anion-exchange chromatography media for antibody flow-through purification. J Chromatogr.A 2007, 1155, 7484

18 Gupta,M.N., Jain,S., and Roy,I. Immobilized metal affinity chromatography without chelating ligands: purification of soybean trypsin inhibitor on zinc alginate beads. Biotechnol.Prog. 2002, 18, 78-81

19 Zhang,C.M., Reslewic,S.A., and Glatz,C.E. Suitability of immobilized metal affinity chromatography for protein purification from canola. Biotechnol.Bioeng. 2000, 68, 52-58

20 Menkhaus,T.J., Eriksson,S.U., Whitson,P.B., and Glatz,C.E. Host selection as a downstream strategy: polyelectrolyte precipitation of beta-glucuronidase from plant extracts. Biotechnol.Bioeng. 2002, 77, 148-154

21 Ramessar,K., Rademacher,T., Sack,M., Stadlmann,J., Platis,D., Stiegler,G., Labrou,N., Altmann,F., Ma,J., Stoger,E., Capell,T., and Christou,P. Cost-effective production of a vaginal protein microbicide to prevent HIV transmission. Proc.Natl.Acad.Sci.U.S.A 2008, 105, 3727-3732

22 Platis,D., Sotriffer,C.A., Clonis,Y., and Labrou,N.E. Lock-and-key motif as a concept for designing affinity adsorbents for protein purification. $\mathrm{J}$ Chromatogr.A 2006, 1128, 138-151

23 Platis,D. and Labrou,N.E. Affinity chromatography for the purification of therapeutic proteins from transgenic maize using immobilized histamine. J Sep.Sci. 2008, 31, 636-645

24 Balasubramaniam,D., Wilkinson,C., Van Cott,K., and Zhang,C. Tobacco protein separation by aqueous two-phase extraction. J.Chromatogr.A 2003, 989, 119-129 
25 Platis,D. and Labrou,N.E. Development of an aqueous two-phase partitioning system for fractionating therapeutic proteins from tobacco extract. J.Chromatogr.A 2006, 1128, 114-124

26 Platis,D., Drossard,J., Fischer,R., Ma,J.-K.C., and Labrou,N.E. New downstream processing strategy for the purification of monoclonal antibodies from transgenic tobacco plants. J Chromatogr.A 2008, 1211, 80-89

27 Andrews,B.A., Nielsen,S., and Asenjo,J.A. Partitioning and purification of monoclonal antibodies in aqueous two-phase systems. Bioseparation. 1996, 6, 303-313

28 Wingren,C., Michaelsen,T.E., Magnusson,C.G., and Hansson,U.B. Comparison of surface properties of human $\operatorname{IgA}$, IgE, IgG and $\operatorname{IgM}$ antibodies with identical and different specificities. Scand.J.Immunol. 1996, 44, 430-436

29 Li,C., Bai,J., Li,W., Cai,Z., and Ouyang,F. Optimization of Conditions for Bacteriocin Extraction in PEG/Salt Aqueous Two-Phase Systems Using Statistical Experimental Designs. Biotechnol.Prog. 2001, 17, 366-368

30 Rosa,P.A., Azevedo,A.M., and Aires-Barros,M.R. Application of central composite design to the optimisation of aqueous two-phase extraction of human antibodies. J.Chromatogr.A 2007, 1141, 50-60

31 Jervis,L. and Pierpoint,W.S. Purification technologies for plant proteins. Journal of Biotechnology 1989, 11, 161-198

32 Loomis,W.D. and Battaile,J. Plant phenolic compounds and the isolation of plant enzymes. Phytochemistry 1966, 5, 423-438

33 Loomis, W.D. Overcoming problems of phenolics and quinones in the isolation of plant enzymes and organelles. Methods Enzymol. 1974, 31, 528-544

34 Smith,D.M. and Montgomery,M.W. Improved methods for the extraction of polyphenol oxidase from d'anjou pears. Phytochemistry 1985, 24, 901904

35 Hagerman,A.E. and Butler,L.G. The specificity of proanthocyanidin-protein interactions. J.Biol.Chem. 1981, 256, 4494-4497

36 Spencer,C.M., Cai,Y., Martin,R., Gaffney,S.H., Goulding,P.N., Magnolato,D., Lilley,T.H., and Haslam,E. Polyphenol complexation--some thoughts and observations. Phytochemistry 1988, 27, 2397-2409

37 Hood,E.E., Kusnadi,A., Nikolov,Z., and Howard,J.A. Molecular farming of industrial proteins from transgenic maize. Adv.Exp.Med.Biol. 1999, 464, $127-147$

38 Woodard,S.L., Mayor,J.M., Bailey,M.R., Barker,D.K., Love,R.T., Lane,J.R., Delaney,D.E., McComas-Wagner,J.M., Mallubhotla,H.D., Hood,E.E., Dangott,L.J., Tichy,S.E., and Howard,J.A. Maize (Zea mays)-derived 
bovine trypsin: characterization of the first large-scale, commercial protein product from transgenic plants. Biotechnol.Appl.Biochem. 2003, $38,123-130$

39 Suzuki,Y.A., Kelleher,S.L., Yalda,D., Wu,L., Huang,J., Huang,N., and Lonnerdal,B. Expression, characterization, and biologic activity of recombinant human lactoferrin in rice. J Pediatr.Gastroenterol.Nutr. 2003, 36, 190-199

40 Yang,D., Guo,F., Liu,B., Huang,N., and Watkins,S.C. Expression and localization of human lysozyme in the endosperm of transgenic rice. Planta 2003, 216, 597-603

41 Arlen,P.A., Falconer,R., Cherukumilli,S., Cole,A., Cole,A.M., Oishi,K.K., and Daniell,H. Field production and functional evaluation of chloroplastderived interferon-alpha2b. Plant Biotechnol.J 2007, 5, 511-525

42 Hart,R.A., Lester,P.M., Reifsnyder,D.H., Ogez,J.R., and Builder,S.E. Large scale, in situ isolation of periplasmic IGF-I from E. coli. Biotechnology (N Y) 1994, 12, 1113-1117

43 Bradford,M.M. A rapid and sensitive method for the quantitation of microgram quantities of protein utilizing the principle of protein-dye binding. Anal.Biochem. 1976, 72, 248-254

44 Snyder,S.M., Cole,K.D., and Szlag,D.C. Phase Compositions, Viscosities and Densities of Aqueous Two-Phase Systems Composed of Polyethylene Glycol and Various Salts at $25^{\circ}$ C. J.Chem.Eng.Data 1992, 37, 268-274

45 Zaslavsky,B.Y. Aqueous Two-Phase Partitioning. 1995, Aqueous Two-Phase Partitioning. 1995, Physical Chemistry and Bioanalytical Applications, Marcel Dekker, New York.

46 Cisneros,M., Benavides,J., Brenes,C.H., and Rito-Palomares,M. Recovery in aqueous two-phase systems of lutein produced by the green microalga Chlorella protothecoides. J.Chromatogr.B Analyt.Technol.Biomed.Life Sci. 2004, 807, 105-110

47 Srinivas,N.D., Barhate,R.S., and Raghavarao,K.S.M.S. Aqueous two-phase extraction in combination with ultrafiltration for downstream processing of Ipomoea peroxidase. J. Food Eng. 2002, 54, 1-6 


\section{Figure Legends.}

Figure 1. Photograph showing differential partitioning of tobacco plant debris to the top and bottom phase at different ATPS conditions. A $20 \mathrm{~g}$ aqueous two-phase systems were used under conditions $10-15 \% \mathrm{w} / \mathrm{w}$ [PEG 1500], 12\% w/w [Pi] at pH 5. The unclarified transgenic tobacco extract load was $8.25 \% \mathrm{w} / \mathrm{w}$.

Figure 2. Contour plots for mAb 2G12 showing the effect of PEG 1500 and phosphate buffer concentration ([Pi], \% w/w) on ATPS bottom phase yield (A) and purification factor (B). $5 \mathrm{~g}$ aqueous two-phase systems were used under conditions dictated by a full central composite design at $\mathrm{pH}$ 5. The unclarified transgenic tobacco extract load was $8.25 \% \mathrm{w} / \mathrm{w}$.

Figure 3. SDS-PAGE analysis of $\mathrm{mAb} 2 \mathrm{G} 12$ and $4 \mathrm{E} 10$ fractionation from transgenic tobacco extract employing the ATPS protocol and the standard Protein A-based purification protocol. The protein bands were stained with Coomassie Blue R-250. Lane 1: crude tobacco extract; Lane 2: dialysed ATPS bottom phase; Lane 3: mAb 2G12 purified by ATPS following by Protein A affinity chromatography; Lane 4: mAb 4E10 purified by ATPS following by Protein A affinity chromatography. 


\section{Table 1.}

Central Composite design for contour surface study of the effect of PEG and phosphate concentration on the bottom phase yield and purification factor of $\mathrm{mAb}$ $2 \mathrm{G} 12$ at $\mathrm{pH}$ 5. The observed $\mathrm{V}_{\mathrm{t}} / \mathrm{V}_{\mathrm{b}}$ ratio has also been documented. Precise measurements of the $\mathrm{K}_{\text {part }}$ for $\mathrm{mAb} 2 \mathrm{G} 12$ and tobacco proteins was not possible when crude unclarified tobacco extract was used due to the increase amount of debris. ND, not determined due to the inability to form biphasic systems.

\section{PEG 1500 (crude)}

order

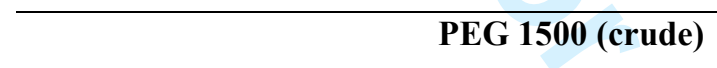

\section{Coded levels}

$\begin{array}{ccccccccc}\text { PEG } & \text { Pi } & \text { PEG } & \text { Pi } & \mathbf{V}_{\mathrm{t}} / \mathrm{V}_{\mathrm{b}} & \text { Yield } & \text { Yield } & \text { Purification } & \text { Purification } \\ (\% \mathrm{w} / \mathrm{w}) & (\% \mathrm{w} / \mathrm{w}) & (\% \mathrm{w} / \mathrm{w}) & (\% \mathrm{w} / \mathrm{w}) & & (3 \mathrm{hrs}) & (24 \mathrm{hrs}) & \text { Factor } & \text { Factor }\end{array}$

\begin{tabular}{crr|rrrrrrr}
1 & 1.000 & -1.000 & 16.00 & 11.00 & 2.1 & 91.2 & 91.7 & 3.5 & 4.4 \\
2 & 0.000 & 0.000 & 14.00 & 13.00 & 1.7 & 79.0 & 74.6 & 3.8 & 3.5 \\
3 & 0.000 & -1.414 & 14.00 & 10.17 & ND & ND & ND & ND & ND \\
4 & 0.000 & 0.000 & 14.00 & 13.00 & 1.7 & 81.9 & 72.1 & 3.5 & 3.8 \\
5 & -1.000 & -1.000 & 12.00 & 11.00 & ND & ND & ND & ND & ND \\
6 & 1.000 & 1.000 & 16.00 & 15.00 & 1.6 & 3.6 & 4.3 & 0.3 & 0.5 \\
7 & 0.000 & 0.000 & 14.00 & 13.00 & 1.6 & 85.8 & 70.2 & 4.3 & 3.2 \\
8 & -1.000 & 1.000 & 12.00 & 15.00 & 1.3 & 56.3 & 50.5 & 2.7 & 2.8 \\
9 & -1.414 & 0.000 & 11.17 & 13.00 & 1.2 & 99.1 & 99.8 & 3.5 & 3.4 \\
10 & 0.000 & 1.414 & 14.00 & 15.82 & 1.5 & 3.8 & 3.9 & 0.3 & 0.3 \\
11 & 0.000 & 0.000 & 14.00 & 13.00 & 1.7 & 85.8 & 78.9 & 4.0 & 3.3 \\
12 & 1.414 & 0.000 & 16.82 & 13.00 & 2.1 & 7.9 & 5.3 & 0.6 & 0.4 \\
13 & 0.000 & 0.000 & 14.00 & 13.00 & 1.7 & 88.4 & 71.3 & 3.9 & 3.7 \\
\hline
\end{tabular}


Table 2. Purification of mAb 2G12 (A) and mAb 4E10 (B) from transgenic tobacco extract using ATPS. Conditions: 13.1\% w/w [PEG 1500], 12.5\% w/w [Pi] at pH 5 with a $\mathrm{V}_{\mathrm{t}} / \mathrm{V}_{\mathrm{b}}$ phase ratio of 1.3 and $8.25 \% \mathrm{w} / \mathrm{w}$ transgenic tobacco extract load.

\begin{tabular}{|c|c|c|c|c|c|}
\hline Step & $\begin{array}{l}\text { Yield } \\
(\%)\end{array}$ & $\begin{array}{c}\text { Purification } \\
\text { Factor } \\
\text { (fold) }\end{array}$ & $K_{\text {part }}^{\text {tobacco }}$ & $\mathrm{K}_{\mathrm{part}} \mathrm{mAb}^{\mathrm{mA} 2 \mathrm{G}}$ & $\mathbf{V}_{\mathbf{t}} / \mathbf{V}_{\mathbf{b}}$ \\
\hline $\begin{array}{c}\text { Crude extract } \\
\text { ATPS } \\
\text { (top phase) } \\
\text { ATPS } \\
\text { (bottom phase) } \\
\text { ATPS bottom phase } \\
\text { after dialysis } \\
\end{array}$ & $\begin{array}{l}100 \\
0.92 \\
95 \\
85 \\
\end{array}$ & $\begin{array}{c}1 \\
0.046 \\
1.37 \\
2.4 \\
\end{array}$ & 0.45 & 0.015 & 1.3 \\
\hline B & & & & & \\
\hline Step & $\begin{array}{l}\text { Yield } \\
(\%)\end{array}$ & $\begin{array}{l}\text { Purification } \\
\text { Factor } \\
\text { (fold) }\end{array}$ & $K_{\text {part }}^{\text {tobacco }}$ & $K_{\text {part }}{ }^{m A b} 4 E 10$ & $\mathbf{V}_{\mathbf{t}} / \mathbf{V}_{\mathbf{b}}$ \\
\hline $\begin{array}{c}\text { Crude extract } \\
\text { ATPS } \\
\text { (top phase) } \\
\text { ATPS } \\
\text { (bottom phase) } \\
\text { ATPS bottom phase } \\
\text { after dialysis }\end{array}$ & $\begin{array}{c}100 \\
0.92 \\
92 \\
84\end{array}$ & $\begin{array}{c}1 \\
0.15 \\
1.83 \\
2.1\end{array}$ & 0.38 & 0.033 & 1.3 \\
\hline
\end{tabular}




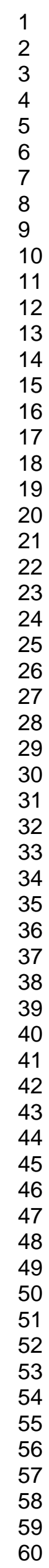

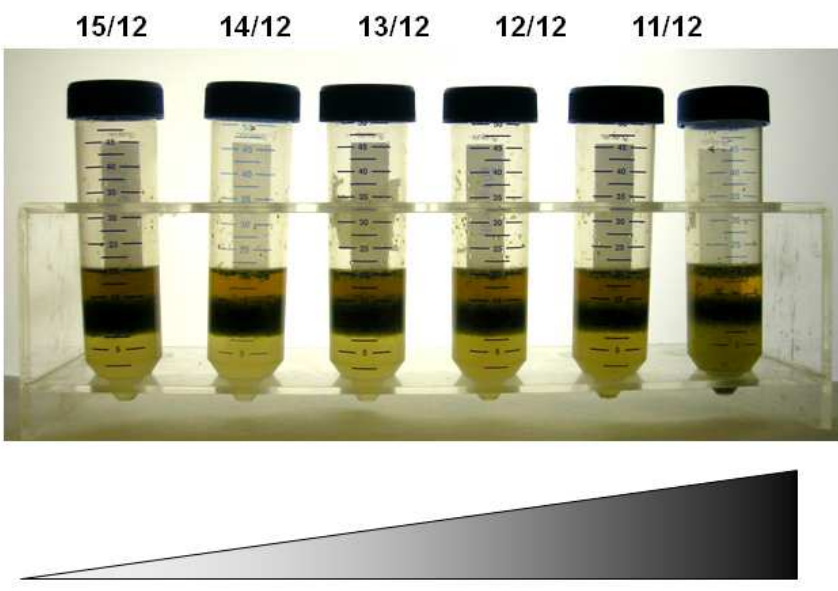

$254 \times 190 \mathrm{~mm}(96 \times 96 \mathrm{DPI})$ 


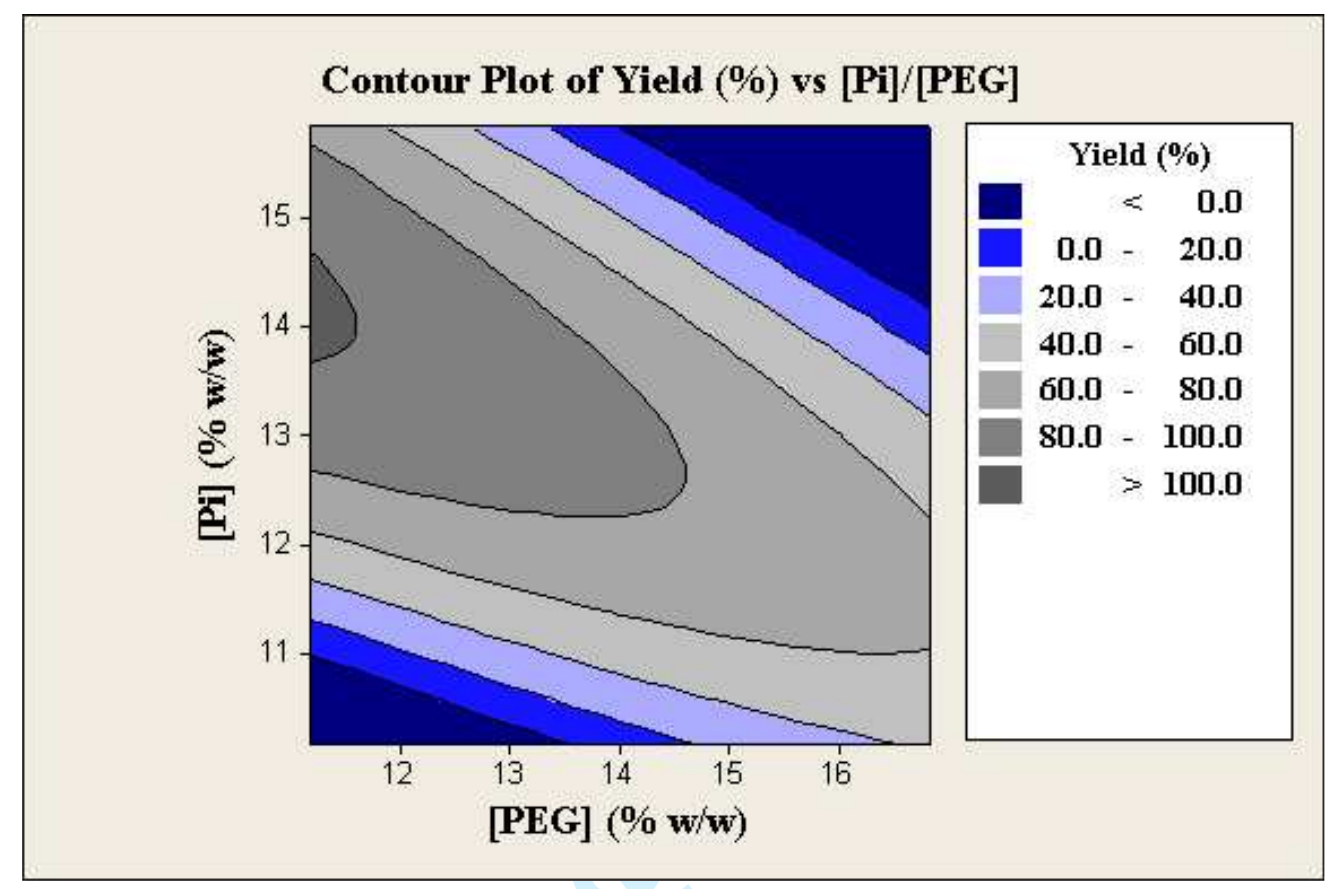

30

31 


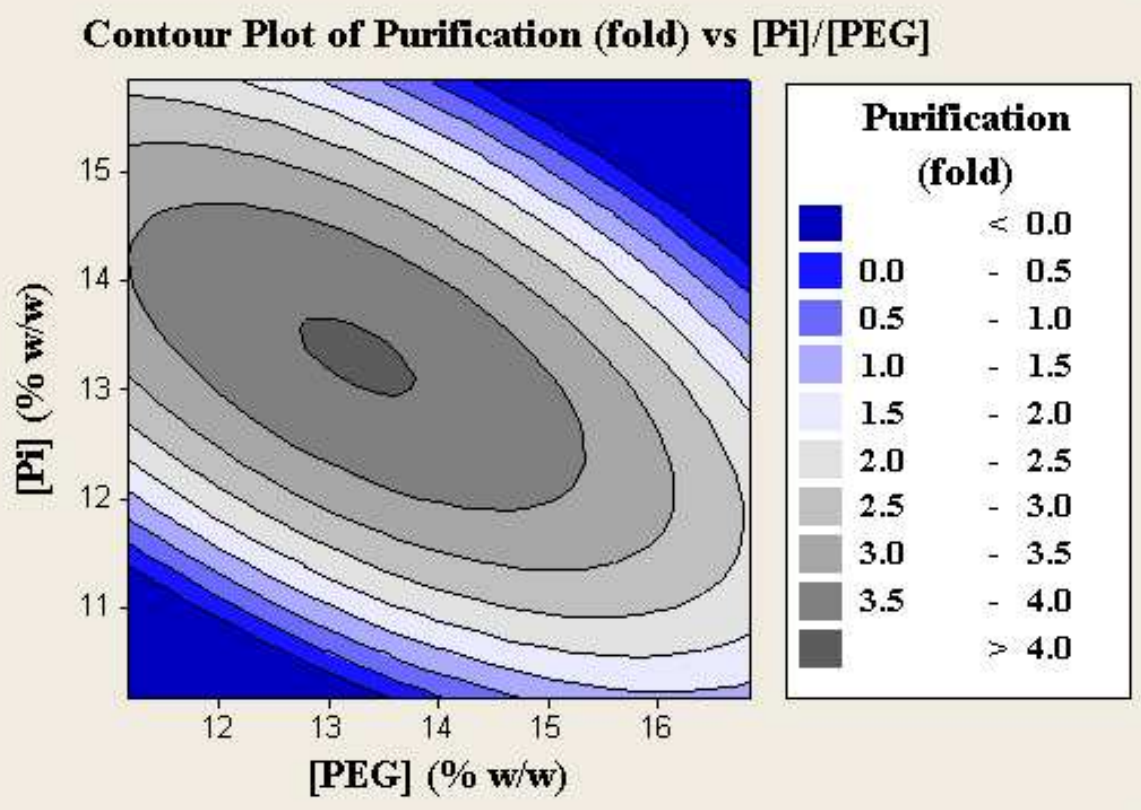




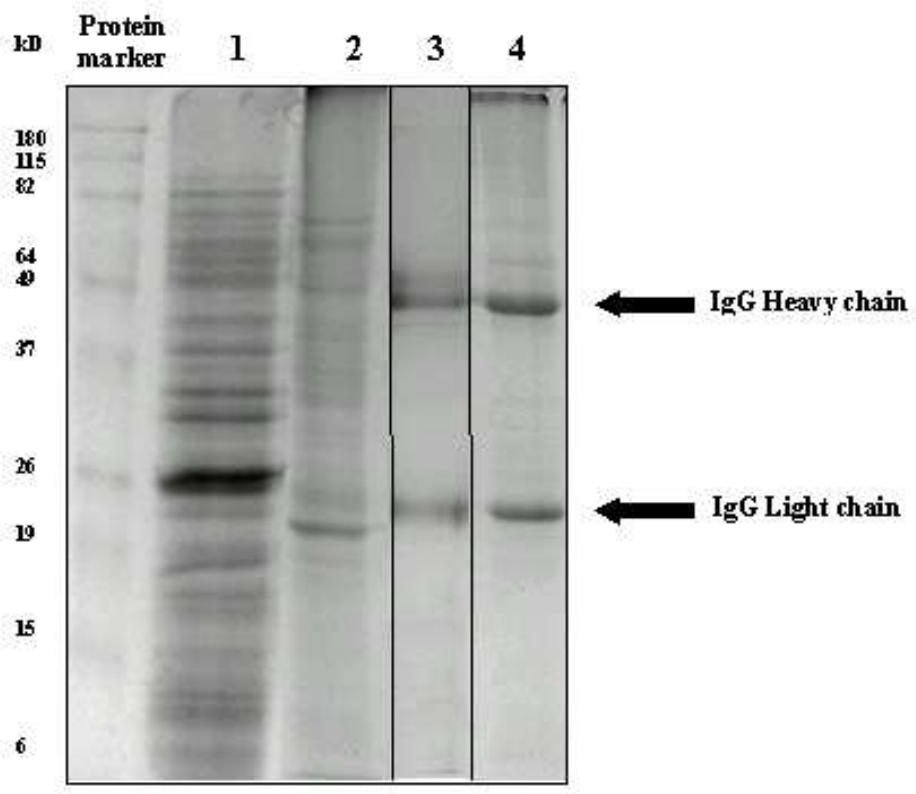

